Юлія Кобюк

Інститут педагогічної освіти і освіти дорослих імені Івана Зязюна НАПН України ORCID ID 0000-0001-8931-1929

DOI 10.24139/2312-5993/2020.02/256-264

\title{
ПРОФЕСІЙНА ПІДГОТОВКА МАЙБУТНІХ УЧИТЕЛІВ ПОЧАТКОВИХ КЛАСІВ В АВСТРАЛІЇ ТА УКРАЇНІ: СПІЛЬНЕ Й ВІДМІННЕ
}

У статті здійснюється порівняльний аналіз австралійського та українського досвіду організачії процесу професійної підготовки майбутніх учителів початкових класів з метою збагачення вітчизняної системи освіти передовим зарубіжним досвідом у цьому напрямі. 3'ясовано, що підготовка майбутніх учителів початкових класів в університетах Австралії та України $\epsilon$ ступеневою. Визначено керівні принципи, що лежать в основі програм підготовки, а саме: логічності, послідовності, відповідності навчальним планам та державним вимогам. Розкрито зміст та визначено спільні й відмінні риси систем професійної підготовки майбутніх учителів початкових класів обох країн.

Ключові слова: квалірікачія, учитель початкових класів, професійна підготовка, програми підготовки, стандарти, професійний досвід.

Постановка

проблеми.

Забезпечення

зростання конкурентоспроможності держави, що багато в чому визначається рівнем освіти, яка становить основу соціального розвитку та сталого економічного зростання країни. В Україні за останні роки здійснено низку заходів щодо модернізації системи вищої освіти, підвищення ії якості, доступності та конкурентоспроможності на світовому ринку. Всі перетворення, що відбуваються, зумовлюють виникнення нових підходів до підготовки майбутнього вчителя початкових класів, який $\epsilon$ початковою ланкою в процесі здобуття освіти кожним громадянином.

Запит суспільства до рівня підготовки вчителя й сучасні умови професійної діяльності вчителя початкових класів пов'язані 3 різноманітністю освітніх систем, варіативністю змістового наповнення початкової освіти і технічного та технологічного забезпечення навчального процесу, розширенням можливостей інформаційних технологій для навчання й необхідністю передбачати результати професійної діяльності все це спонукає до виявлення напрямів оновлення змісту та характеру підготовки майбутнього вчителя початкової школи, що в свою чергу передбачає вивчення передового зарубіжного досвіду.

Аналіз актуальних досліджень. Теоретичну і практичну цінність для нашого дослідження становлять праці 3 методології порівняльних досліджень Н. Авшенюк, Н. Бідюк, М. Лещенко, О. Локшиної, Н. Мукан, Л. Пуховської, А. Сбруєвої та ін. Вагомим джерелом у вивченні Австралійської системи освіти та дослідженні питання професійної підготовки майбутніх учителів є праці зарубіжних науковців: А. Баркана (Alan Barcan), А. Велша 
(Anthony Welsh), Б. Колдвелла (Brian Caldwell), Б. Лінгарда (Bob Lingard), К. Марша (Colin Marsh), А. Остіна (Albert Austin), Р. Стівенса (Robert Stevens) та ін.

Мета статті. Ознайомлення з науковими розвідками українських учених у визначеному напрямі засвідчило, що питання професійної підготовки майбутніх учителів початкових класів в університетах Австралії $\epsilon$ актуальною, але недостатньо вивченою проблемою, що зумовило вибір теми нашого дослідження: «Професійна підготовка майбутніх учителів початкових класів в Австралії та Україні: спільне й відмінне». Порівняльний аналіз австралійської та вітчизняної системи підготовки, визначення спільних та відмінних рис допоможе краще усвідомити перспективи розвитку Української системи педагогічної освіти.

Виклад основного матеріалу. Аналіз наукової літератури свідчить, що найхарактернішою рисою систем педагогічної освіти України та Австралії $\epsilon$ різноманітність, що зумовлюється національними особливостями й соціальними умовами розвитку цих країн. Проте загальним для обох систем педагогічної освіти є відповідність вимогами до підготовки вчителів із боку держави, суспільства та залежність від світових тенденцій розвитку освіти.

Під час порівняльного аналізу підготовки майбутніх учителів початкових класів України й Австралії бралися до уваги такі ознаки, як: ступеневість, типи програм, цикли та зміст підготовки, обсяг навчального навантаження студентів, планування педагогічної практики, форми організації навчальних занять, технології навчання, вимоги до випускника, можливості працевлаштування. Нами було з'ясовано, що підготовка майбутніх учителів початкових класів в університетах Австралії $€$ ступеневою (бакалавр - магістр - доктор), так само як і в Україні (молодший бакалавр бакалавр -магістр). В австралійській системі підготовки фахівців, що на одному освітньо-кваліфікаційному рівні присвоюються різні кваліфікації, що засвідчує гнучкість освітньої системи Австралії та створює широкий освітній вибір для абітурієнта. В Україні в освітньо-професійній програмі окремо зазначається рівень, спеціальність та кваліфікація. У навчальних планах, крім цього, зазначаються також додаткові спеціальності: практичний психолог, учитель іноземної мови тощо.

Для студентів Австралії навчальний рік збігається з календарним роком, що починається в січні-лютому і закінчується в листопаді-грудні. Заклади вищої освіти зазвичай мають два семестри 3 оцінюваннями навчальних досягнень, що здебільшого проводяться в формі іспиту в червні та листопаді. Тривалі перерви на літній відпочинок (канікули) тривають із листопада по лютий. Деякі заклади вищої освіти запровадили третій навчальний семестр, який проходить у літні місяці. В Українських університетах навчання ж розпочинається у вересні і закінчується в червні. Канікули тривають з липня по серпень включно. Навчальний рік, так само як і 
в Австралії, складається з двох семестрів у кінці яких відбувається оцінювання навчальних досягнень, у кінці другого семестру, за результатами досягнутого рівня знань та вмінь відбувається перехід на наступний навчальний рік.

Порівнюючи зміст та структуру навчальних планів і програм, зазначимо, що освітні стандарти, відповідно до закону України «Про вищу освіту», поділяються на освітньо-кваліфікаційні характеристики, освітньо-професійні програми та засоби діагностики якості освіти (Про вищу освіту, 2014). Вітчизняні університети впорядковують та розробляють програми підготовки на рівні кафедр та факультетів керуючись вимогами Міністерства освіти і науки України. Програми підготовки побудовані з дотриманням принципів логічності, послідовності й відповідності навчальному плану. Крім того, чітко визначено мету та завдання кожної дисципліни, подано перелік знань та вмінь, які повинні набути студенти після вивчення кожного предмета. Також у програмах визначається загальна кількість годин та їх розподіл між аудиторними та самостійними видами роботи (Калита, 2015). Аналогічно побудовані програми підготовки в австралійських університетах, що розробляються на основі стандартів акредитації програм підготовки, стандартів навчання й викладання та стандартів кваліфікацій, в основу яких покладено Австралійську рамку кваліфікацій (Australian qualifications framework, 2013). Професійна підготовка всіх педагогів також повинна відповідати Австралійському професійному стандарту вчителів (Australian Professional Standards for Teachers, 2011).

В університетах Австралії існують добре розроблені процеси затвердження програм підготовки вчителів. Спеціально створені державні організації слідкують за тим, щоб вони відповідали вимогам та потребам державних департаментів освіти. Як правило, керівні органи влади, державні та територіальні відділи освіти, схвалюють або затверджують програми підготовки вчителів як такі, що готують до впровадження державних шкільних програм. У деяких штатах затвердження програм відбувається через співпрацю університетів із роботодавцями. Хоча курси підготовки викладачів можуть проходити через кілька процесів «схвалення» або «затвердження», тільки в Квінсленді і Вікторії ці процеси чітко сформульовані з урахуванням усіх вимог і стандартів.

Аналізуючи зміст програм підготовки майбутніх учителів початкових класів в австралійських університетах, можемо сказати, що майже всі предмети $\epsilon$ інтегрованими курсами та носять практико-орієнтований характер. Програми підготовки майбутніх учителів у вітчизняних університетах побудовані за предметним принципом і дають належну теоретичну і практичну підготовку. На нашу думку, це не сприяє глибокому теоретичному розумінню психо-фізіологічних особливостей дітей молодшого шкільного віку, сприяє усвідомленню дитини як об'єкта й суб'єкта виховання, глибокому вивченню змісту та методів навчання й 
виховання молодших школярів. Важливим аспектом у професійній підготовці майбутніх учителів початкових класів в Австралії $є$ підготовка до роботи в мультикультурному та інклюзивному середовищі (Огієнко, 2019). Адже різноманітність учнів у школах вимагає, щоб учителі готувалися до спілкування з учнями, які мають різну культуру та мову й мають певні труднощі або перешкоди в навчанні. Таким чином, обов'язковими курсами в австралійських університетах $\epsilon$ такі, що готують до роботи 3 обдарованими дітьми, 3 дітьми 3 особливими потребами та представниками корінного населення. В Українських університетах на сьогодні підготовці до роботи в класах, де $\epsilon$ діти з особливими потребами, приділяють значну увагу. Загалом професійно орієнтованим предметам приділяється достатня увага як в університетах України, так і Австралії.

Як показав аналіз програм підготовки майбутніх учителів початкових класів в австралійських університетах, значне місце в процесі професійної підготовки посідає професійний досвід, який здобувається в процесі проходження педагогічної практики. Слід також зауважити, що в Австралійській педагогічній науці замість слова «практика» використовується термін «професійний досвід», який, на думку науковців, краще відображає сутність багатьох програм підготовки вчителів (Cheryl, 2006). Спільним для обох країн $€$ те, що протягом цього періоду, який займає близько $25 \%$ часу навчання в університеті, майбутні вчителі спостерігають учителів-практиків на робочому місці, та беруть активну участь у шкільному житті. Основною метою здобуття професійного досвіду для майбутніх учителів $€$ ознайомлення з програмами та навчальним планом, практика в роботі з окремими групами учнів, взяття на себе ролі вчителя, взаємодія з педагогічним колективом, учнями та батьками, удосконалення навичок спостереження, вироблення вміння застосовувати теоретичні знання на практиці (Глушок, 2014).

По всій Австралії існує значна різниця в тривалості професійного досвіду. Мінімальна кількість днів, що повинні виділяти педагогічні освітні програми на професійний досвід визначається австралійськими стандартами. У загальному в чотирирічних бакалаврських програмах кількість днів становить від 95 до 140 днів, від 40 до 65 у програмі післядипломної освіти, що триває один рік, та від 50 до 115 у дворічних курсах післядипломної освіти. Проте розподіл часу, що виділяється, структура та терміни професійного досвіду відрізняються між університетами. Багато програм підготовки вчителів початкових класів в Австралії виділяють час, який задовольняє мінімальні вимоги стандартів професійної підготовки (Ingvarson, 2014). В Українських університетах бакалаври проходять приблизно 60 - 85 днів; магістри - від 25 днів до 40 днів.

у більшості програм підготовки вчителів початкових класів, що пропонуються університетами Австралії, як і в Україні, професійний досвід 
починається з коротких періодів ознайомлення та спостереження в школах, що веде від обмеженого навчання в малих групах та допомоги вчителеві, до відповідальності за цілий клас. Ця послідовність розвивається поступово, починаючи з ознайомлення до прийняття повної відповідальності за клас. Оскільки студенти проходять практику на різних етапах свого навчання, вони беруть на себе більшу ступінь відповідальності у класах і роль між викладачем і студентом змінюється від спостерігача до колеги (Craven, Beswick, Fleming, Fletcher, Green, Jensen, Leinonen, \& Rickards, 2014).

У процесі набуття професійного досвіду важливою складовою $\epsilon$ взаємодія з керівником, наставником, та ментором, який забезпечує керівництво й наставництво, надає відгуки на педагогічну практику та сприяє оцінюванню студентів. Наявність такого спеціаліста є центральним завданням для підтримки майбутніх фахівців, та забезпечення якісного професійного досвіду.

Щодо організації навчальних занять в університетах України й Австралії, то такі форми, як лекції, семінари, самостійна робота $є$ спільними для обох освітніх систем, проте в Австралії на самостійну роботу відводиться більша кількість часу), що сприяє розвиткові самоосвіти студентів. Поширеними також $є$ індивідуальні та групові консультації, онлайн дискусії, мультимедійні, тренінгові, інформаційні, ігрові технології та ін.

Важливо також зауважити те, що Австралія - це країна з високим розвитком інформаційних технологій. В австралійській навчальній програмі студенти активно розвивають можливості ІКТ, оскільки вони вчаться ефективно й належним чином використовувати технології для доступу, створення і передачі інформації та ідей, вирішення проблем і спільної роботи в усіх сферах навчання. Ця здатність дозволяє вчитися максимально використовуючи цифрові технології, доступні їм, адаптуючись до нових способів роботи з розвитком технологій і обмежуючи ризики для себе та інших в цифровому середовищі (Chalich, 2015).

На сучасному етапі розвитку технологій, та їх упровадження в освітній процес, великої популярності набувають онлайн-технологій навчання, що забезпечують дистанційне навчання. Зі зростанням популярності онлайн навчання та визнанням цінності, яку воно може принести, заклади вищої освіти почали включати його елементи у свої звичайні методи навчання. Основним фактором, що впливає на успішне впровадження технологій онлайн-навчання у вищій освіті, $є$ утворення та підтримання процесів, що створюють стійкі умови і забезпечують засоби для постійної та самостійної діяльності.

Педагогічний підхід, що спирається на кращі риси онлайн навчання, набирає популярність під назвою змішаного навчання (blended learning). Його переваги полягають у тому, що воно дозволяє університетам визначати й вибирати бажане поєднання індивідуальних, інтерактивних і самоосвітніх 
режимів у залежності від аудиторії і ресурсів, що можуть бути мобілізовані. Різні програми можуть мати різні поєднання режимів, компонентів і бути адаптовані до вимог конкретного навчального середовища. Можливості включають гнучкість, простоту доступу, інтеграцію складних мультимедійних та інтерактивних технологій. Університети, експериментуючи зі змішаним навчанням, виявили, що цей підхід є більш ефективним, ніж використання звичайного навчання або тільки онлайн-навчання. Одна з найбільш цікавих можливостей, пропонованих змішаним навчанням, полягає в тому, щоб персоналізувати навчання відповідно до своїх уподобань або здібностей. Це досягається за рахунок забезпечення гнучкості в змісті та адаптації до потреб студента (Santhiram, 2016). Дослідження показують, що в австралійських університетах студенти беруть активну участь у процесі навчання. Акцент робиться на здатності нестандартно, незалежно і критично мислити, брати участь у дискусіях і працювати в команді. В українських університетах використання інформаційних технологій ще не носить масовий характер, проте широко розповсюдженим є застосування окремих технологій, таких як: дистанційного навчання, мультимедійні, інформаційно-комунікаційні та ін. (Годлевська, 2012).

Університетська освіта обох країн спрямована на розвиток академічних та практичних навичок, а також забезпечення платформи для подальшого професійного та особистісного зростання. Учителі, які отримали якісну професійну підготовку, повинні володіли і проявляли такі ознаки: високий рівень знань, уяви; багатий набір навичок, методів і підходів, які вони можуть використовувати, щоб забезпечити правильне їх поєднання для задоволення конкретних потреб окремих учнів; розуміння потреб учнів, за яких вони несуть відповідальність; здатність викликати високий рівень поваги й навіть прихильності з боку своїх учнів і колег; великий потенціал для участі в професійному навчанні за допомогою професійного розвитку; здатність і готовність робити внесок у професійне навчання інших; лідерство і приклад високих цінностей і якостей і прагнуть заохочувати до цього інших.

Після завершення навчання випускники можуть подавати документи в органи реєстрації вчителя початкової школи, а також мають можливість розпочати деякі з наступних шляхів кар'єри: учитель початкових класів, виконавчий та директор школи, службовець зі зв'язків батьків зі школою, шкільний вихователь, бібліотекар, помічник учителя, викладач, службовець із культурної освіти аборигенів (The University of Newcastle, 2016).

Дослідження показують, що на сьогодні Австралія, як і Україна, не в змозі утримати в школах висококваліфікованих учителів. Темпи знецінення професії викликають занепокоєння та привертають високу увагу не лише науковців, але й урядові організації. Статистичні дані свідчать, що від 30 \% до 50 \% педагогів звільняються в перші п'ять років своєї роботи. Така різниця в 
результатах зумовлена тим, що кожен штат та територія збирає власну статистику, і немає чітко встановленого механізму відстеження рухів між освітніми системами (Teachers are leaving, 2016). Проте, завдяки новій освітній політиці уряду Австралії (пільги, дотації) відбувається підняття престижу професії вчителя. Доцільно зауважити, що не лише вчителіпочатківці, як і вчителі зі стажем роботи, отримують активну підтримку на державному рівні. Непрестижність та низька оплачуваність педагогічної професії в Україні зумовлює докорінну зміну сфери трудової діяльності, наслідки цих втрат далекосяжні. На національному рівні це означає часткову втрату інвестицій у підготовку вчителів, втрату професійного досвіду, збільшення навантаження на працюючих учителів, підвищення попиту на вчителів початкових класів тощо (Teachers are leaving, 2016).

Загалом, на всіх рівнях освітнього середовища Австралії та України спостерігається зростання інвестицій у підготовку вчителя через урядову підтримку шляхом запровадження проектів, програм і документів на загальнонаціональному та регіональному рівнях, спрямованих на підвищення якості професійної підготовки вчителів початкових класів.

Висновки. Порівняльно-педагогічний аналіз особливостей професійної підготовки вчителів початкових класів в Австралії та Україні дав змогу виявити спільні та відмінні риси. Загалом, в обох країнах підготовка вчителів початкових класів здійснюється на засадах компетентнісного й особистісно-орієнтованого підходів із урахуванням принципів безперервності, імплементації зарубіжного досвіду, інноваційності, науковості, добровільності навчання, демократизації навчання, спрямованих на всебічний гармонійний розвиток. Дослідження показують, що інвестування в підготовку вчителів початкових класів має великий потенціал для підвищення якості навчання дітей у школі.

Оскільки на сучасному етапі реформування української освіти якісна підготовка фахівців цього профілю набуває особливого значення, австралійський досвід професійної підготовки вчителів початкових класів $€$ цінним.

Перспективи подальших наукових розвідок. Проведене дослідження не вичерпує всіх аспектів порушеної проблеми. Перспективу їі подальшого наукового пошуку вбачаємо в подальшому порівняльному дослідженні законодавчої бази професійної підготовки вчителів початкових класів обох країн.

\section{ЛITЕРАТУРА}

Глушок, Л. М. (2014). Профресійна підготовка фрахівців дошкільної освіти в університетах Австралії (дис. канд. пед. наук). Хмельницький (Hlushok, L. M. (2014). Professional training of pre-school education professionals at Australian universities (PhD thesis). Xmelnytskyi).

Годлевська, К. (2012). Особливості використання мультимедіа технологій в професійній підготовці майбутніх вчителів початкових класів. Київ: Прінт Квік 
(Hodlevska, K. (2012). Features of the use of multimedia technologies in the professional training of future primary school teachers. Kyiv: Quick Print).

Калита, Н. (2015). Підготовка вчителя початкової школи в контексті сучасних освітніх парадигм. Актуальні питання гуманітарних наук, 14, 265-269 (Kalita, N. (2015). Elementary school teacher training in the context of contemporary educational paradigms. Topical Issues in the Humanities, 14, 265-269).

Огієнко, О.І. (2019). Полікультурність як провідний принцип функціонування систем вищої освіти США, Канади, Великої Британії і Австралії. Педагогічні науки: теорія, історія, інноваційні технології, 7 (91), 254-264 (Ohiienko, О. І. (2019). Multiculturalism as a Leading Principle for the Functioning of Higher Education in the US, Canada, the United Kingdom and Australia. Pedagogical sciences: theory, history, innovative technologies, 7 (91), 254-264).

Україна. Верховна Рада. Закон. (2014). Про вищу освіmу. URL: http://zakon3.rada.gov.ua/laws/show/1556-18 (Ukraine. Verkhovna Rada. Law. (2014). On higher education. Retrieved from: http://zakon3.rada.gov.ua/laws/show/1556-18.

Australian Institute for Teaching and School Leadership. (2011). Australian professional standards for teachers. Retrieved from: https://www.aitsl.edu.au/australianprofessionalstandards-for-teachers/standards/list.

Australian Qualifications Framework. (2013). Retrieved from: http:// www.aqf.edu.au/aqf/the-aqf-second-edition-january-2013/Australian.

Chalich, Z. (2015). Integrating Technology With Classroom Pedagogy - Accelerate Student Learning. Retrieved from: https://educationtechnologysolutions.com.au/2015/08/integrating-technology-withclassroom-pedagogy-accelerate-student-learning/.

Cheryl, S. (2006). A National Overview of Teacher Education in Australia. Queensland: College Year Book.

Craven, G., Beswick, K., Fleming, J., Fletcher, T., Green, M., Jensen, B., Leinonen, E., \& Rickards, F. (2014). Action Now: Classroom Ready Teachers. Retrieved from: https://docs.education.gov.au/system/files/doc/other/action now classroom ready teachers print.pdf.

Ingvarson, L., Reid, K., Buckley, S., Kleinhenz, E., M asters, G., Rowley, G. (Sept, 2014). Best Practice Teacher Education Programs and Australia's Own Programs. Canberra: Department of Education.

Santhiram, R. (Ed). (2016). Emerging Trends in Higher Education Pedagogy. Wawasan: WOU Press.

Teachers are leaving the profession - here's how to make them stay. (2016). Retrieved from: http://theconversation.com/teachers-are-leaving-the-profession-heres-how-tomake-them-stay-52697.

The University of Newcastle. (2016). Retrieved from: https://www.newcastle.edu.au/degrees/master-teaching-primary.

\section{PEЗЮME}

Кобюк Юлия. Профессиональная подготовка будущих учителей начальных классов в Австралии и Украине: общее и отличительное.

В статье осуществляется сравнительный анализ австралийского и украинского опыта организации прочесса профессиональной подготовки будущих учителей начальных классов, с целью обогащения отечественной системы образования передовым зарубежным опытом в этом направлении. Выяснено, что подготовка будущих учителей начальных классов в университетах Австралии и 
Украины является ступенчатой. Определены руководящие принципы, лежащие в основе программ подготовки, а именно: логичности, последовательности, соответствия учебным планам и государственным требованиям. Раскрыто содержание и определены общие и отличительные черты систем профессиональной подготовки будущих учителей начальных классов обеих стран.

Ключевые слова: квалификация, учитель начальных классов, профессиональная подготовка, программы подготовки, стандарты, профессиональный опыт.

\section{SUMMARY}

Kobiuk Yulia Vocational training for future primary school teachers in Australia and Ukraine: common and different.

The article provides a comparative analysis of the Australian and Ukrainian experience in organizing the process of vocational training of future primary school teachers, with the aim of enriching the domestic education system with advanced foreign experience in this direction. It has turned out that training of future primary school teachers in universities in Australia and Ukraine is stepwise. The guiding principles underlying the training programs are defined, namely: consistency, compliance with curricula and state requirements. In total, Australian universities have well-developed processes for approving teacher training programs and are under the strict control of specially created state organizations. Analyzing the content of training programs for future primary school teachers in Australian universities, it was concluded that almost all subjects are integrated courses and are practice-oriented in nature, while training programs for future teachers in domestic universities are built on the subject principle and give an appropriate theoretical and practical training. An analysis of the training programs for future primary school teachers at Australian universities has shown that professional experience occupies a significant place in the training process. In most training programs, professional experience gradually leads from limited small group instruction and teacher assistance to responsibility for the whole class. The main purpose of gaining professional experience is to become familiar with the programs and curriculum, to take on the role of a teacher, to interact with the teaching staff, students, parents, improve observation skills, and develop the ability to put theoretical knowledge into practice. It is also important to note that Australia is a country with a high development of information technology. In the Australian curriculum, students learn to use technology effectively, which allows them to learn by adapting to new ways of working as technology develops and limiting risks for themselves and others in the digital environment. A comparative pedagogical analysis of the features of vocational training of primary school teachers in Australia and Ukraine revealed the common and distinctive features of vocational training systems for future primary school teachers in both countries. In general, in both countries, the training of primary school teachers is carried out on the basis of competence-based and personality-oriented approaches, taking into account the principles of continuity, implementation of foreign experience, innovativeness, science, volunteerism, democratization of education, etc.

Keywords qualification, primary school teacher, professional training, training programs, standards, professional experience. 